\title{
Free Fatty Acid-Glucagon Feed-Back Mechanism
}

\author{
R. Gross and P. Mialhe \\ Institut de Physiologie Générale, Université Louis Pasteur, Strasbourg, France \\ Received: November 8, 1973, and in revised form: March 25, 1974
}

\begin{abstract}
Summary. In order to study the existence of a free fatty acid-glucagon feed-back mechanism in vivo, adult male Peking ducks were infused with 2 physiological fatty acids: oleic and linoleic acids. The animals received IV infusions of $0.365 \mathrm{~g} \mathrm{FFA} / \mathrm{kg} / 30 \mathrm{~min}$ as an emulsion in their own plasma drawn a few weeks earlier. After 5 min of infusion a significant fall of the circulating GLI level occured; it dropped to $50 \%$ of the pre-infusion value after $30 \mathrm{~min}$ infusion. Simultaneously slight hypoglycemia developed. The nature of the GLI involved was established by repeating these experiments
\end{abstract}

with totally pancreatectomized animals (only gut GLI) and partially eviscerated ones (only pancreatic IRG); in the last group the basal level of circulating FFA was slightly reduced. These experiments showed that the pancreatic IRG was involved in this feed-back mechanism which might be non-insulin-dependent. In addition, an intestinal factor could be involved in fasting FFA mobilization.

Key words: Duck, feed-back mechanism, glucagon, FFA, fasting, intestinal lipolytic factor.
The relationship between pancreatic glucagon (IRG) and plasma free fatty acids (FFA) has already been studied by several workers.

Intraportal infusions of physiological concentrations of glucagon provoke a delayed rise in peripheral FFA in dogs and man [27]. An earlier rise in plasma FFA in response to a glucagon infusion can only be realised if the insulinogenic effect of glucagon is reduced by starving the dogs for three days [36].

Conversely, the infusion of triglycerides and heparin, which produces an increase in circulating FFA, induces a decrease in peripheral glucagon immunoreactivity (GLI) in dogs [28]; this GLI is known to be of pancreatic origin as peripheral plasma variations parallel changes in the pancreaticoduodenal vein concentration [38].

A negative feed-back relationship between glucagon and FFA would seem to be present in mammals; but there is no proof that this is either a rapid or a sensitive interplay.

In birds, the situation is somewhat different. Several authors have pointed out the unequivocal lipolytic effect of glucagon and the extreme sensivity of avian adipose tissue to this hormone: in chickens $[10,14,21]$, in owls [13], and in ducks $[10,7]$. Its remarkably high activity would seem to be because insulin is devoid of an antilipolytic effect in birds $[11,5]$; the insulin secretion induced by glucagon does not interfere with the lipolytic effect of glucagon in this species. The duck therefore appeared particularly appropriate for studies on a glueagon-FFA feed-back mechanism. Another reason which prompted us to use it as a,n experimental animal was that total pancreatectomy is followed by a drop in plasma FFA [6].

In the present paper we wish to demonstrate the existence of a glucagon-FFA feed-back mechanism in physiological conditions. To do this, we studied the effect of an infusion of oleic or linoleic acid on plasma levels of pancreatic and gut glucagon. The amounts of fatty acids were those calculated to mimic the normal doubling of FFA concentration which accompanies an overnight fast. We also examined the functioning of such a feed-back mechanism in diabetic animals. This was considered important in the light of other results implying an impairment of the glucagon-glucose feedback mechanism during diabetes in man and dog [40, $35]$, and the goose and duck [18].

\section{Material and Methods}

\section{Animals}

The 90 adult male Peking ducks used were maintained on a normal fowl diet (Fortis Dusquesne) and tap water. They weighed between 1.6 and $2.5 \mathrm{~kg}$. Before the experiments they were transferred indoors, installed in individual cages, and fasted for $16-20 \mathrm{~h}$.

\section{Operations}

1. Total and Subtotal Pancreatectomies. The operations were performed according to the technique detailed by Mialhe [32]. In the subtotally depancreatized ducks the anterior part of the splenic lobe (representing 1 to $2 \%$ of the pancreas) is left.

2. Partial Evisceration. The duodenum of the duck, unlike that of mammalian species, is devoid of GLI activity [19]; this means that it can be retained without prejudicing plasma GLI levels. Partial eviscerations, in which the pancreas and duodenum are left attached, were performed according to the procedure of Krug and al. [20]: the plasma GLI is then of pancreatic origin. 
only the first metabolite requires the presence of insulin. This conclusion may not be valid in mammals as the high levels of FFA observed in diabetes $[2,3,24]$ would be expected to reduce glucagon secretion; apparently however, they do not $[2,40,35]$.

\section{Relative Importance of the Glucose-Glucagon and FFA-Glucagon Feed-Back Mechanisms}

Studies on this problem have so far yielded contradictory results. Data obtained [8] with isolated guinea pig islets suggested that FFA were stronger inhibitors of glucagon secretion than glucose. With an isolated perfused rat pancreas preparation, FFA were con. cluded to have an important, but not predominant, role in the regulation of glucagon output [29]. The slight decrease of the plasma glucose level observed during the course of the oleic acid infusion in normal and partially eviscerated ducks, may reduce the effects of the increased FFA level. Indeed, an important decrease of plasma GLI or pancreatic glucagon is noted during the first ten minutes of infusion; no further decrease is observed unless the concentration of FFA in the perfusate is subsequently increased; in that situation, the secondary hypersecretion of glucagon is suppressed, probably by the high level of FFA.

We know that the glucose-glucagon feed back mechanism is extremely sensitive in a species very similar to the duck, the goose [39]; a variation of the basal glucose level of $5 \%$ is enough to bring about a change in the plasma glucagon level. In our experiments on partially eviscerated ducks, a significant decrease of plasma pancreatic IRG is induced by increasing the basal EFA by 190\%: the FFA-glucagon feed-back mechanism therefore seems to be less sensitive than the glucose-glueagon one. However observations on starved ducks $[36,7]$ show no change in plasma GLI when plasma FFA are doubled, and plasma glucose reduced by $10 \%$. We are therefore unable to assess the relative importance of the two feed-back mechanisms in the duck.

\section{Regulation of FFA Level in the Duck}

After total pancreatectomy, the blood glucose level decreases very rapidly, but the FFA level is normal at the time of the infusion. A factor other than pancreatic glucagon, must be responsible for the maintenance of FFA levels. This is also suggested by the fact that there is a decrease in the plasma FFA level after partial evisceration yet the plasma pancreatic IRG remains within the normal range. These observations are in accordance with the postulated existence of intestinal lipolytic factors [21].

\section{Conclusion}

A free-fatty acid-pancreatic glucagon feed-back mechanism working in physiological conditions has been demonstrated in the duck; it might be non-in- sulin dependent. Gut GLI is not involved in this regulation.

Pancreatic glucagon does not seem to be the only factor responsible for the maintenance of FFA level in fasting ducks.

Acknowledgements. The authors wish to thank Miss M. Horrenberger, Mrs M. Roth and Mrs G. Sommermeyer for their skilled technical assistance and Miss E. Krug for the English corrections of the manuscript.

\section{References}

1. Antonis, A.: Semiautomated method for the colorimetric determination of plasma FFA. J. Lipid Res. 6, 307-312 (1965)

2. Assan, R., Hautecouverture, G., Guillemant, S., Dauchy, F., Protin, P., Derot, M.: Evolution de paramètres hormonaux (glucagon, cortisol, $\mathrm{STH}$ ) et énergétiques (glucose, acides gras libres, glycérol) dans 10 acidocétoses diabétiques graves traitées. Path. et Biol. 17, 1095-1105 (1965)

3. Bierman, E., Dole, B.P., Roberts, T.N.: An abnormality in non esterified fatty acid metabolism in diabetes mellitus. Diabetes $6,475-479$ (1957)

4. Clement, G.: Personal communication

5. Desbals, P., Desbals, B., Agid, R., Mialhe, P.: Pancreatic regulation of lipolysis in the duck. Diabetologia 6, $42(1970)$

6. Desbals, P., Desbals, B., Mialhe, P.: Variations des lipides plasmatiques et hépatiques chez le canard totalement dépancréaté. J. Physiol. 59, 232 (1967)

7. Desbals, P.: Effets de la pancréatectomie et de l'hypophysectomie sur la circulation des lipides chez le canard. Thesis Univ. Toulouse (1972)

8. Edwards, J.C., Taylor, K.W.: Fatty acids and the release of glucagon from isolated guinea-pig islets of Langerhans incubated in vitro. Biochern. Biophys. Acta 215, 310-315 (1970)

9. Goodman, D.S.: The interaction of human serum albumin with long chain fatty acids anions. J. Amer. Chem. Soc. 80, 3892-3898 (1968)

10. Grande, F.: Effect of glucagon on plasma free fatty acids and blood sugar in birds. Proc. Soc. exp. Biol. 128, 532-536 (1968)

11. Grande, F.: Lack of insulin effect on free fatty acids mobilization produced by glucagon in birds. Proc. Soc. exp. Biol. 130, 711 - 713 (1969)

12. Grande, F., Prigge, W.: Glucagon infusion, plasma free fatty acids and triglycerides, blood sugar and liver lipids in birds. Amer. J. Physiol. 218, 1406-1411 (1970)

13. Grande, F.: Effects of glucagon and insulin on plasma free fatty acids and blood sugar in owls. Proc. Soc. exp. Biol. 133, 540-543 (1970)

14. Heald, P.J., Mc Lachlan, P.M., Rookledge, K.A.: The effects of insulin, glucagon and adrenocorticotrophic hormone on the plasma glucose and free fatty acids of the domestic fowl. J. Endocr. 33, 83-95 (1965)

15. Hillyard, L.A., Cornelius, C.A., Chaikoff, I.L.: Romoval by the isolated rat liver of palmitate-1-C and cholesterol-4-C in chylomicrons from perfusion fluid. J. biol. Chem. 234, 2240-2245 (1969)

16. Hoffman, W.S.: A rapid method for the determination of glucose in blood and urine. J. biol. Chem. 120, 51 (1937)

17. Itaya, K., Ui, M.: Colorimetric determination of free fatty acids in biological fluids. J. Lipid Res. 6, 16-20 (1965) 
18. Karmann, H., Mialhe, P.: Mécanisme de feed-back glucose-glucagon chez les oies et les canards normaux et diabétiques. In "Abstracts VIII An. Meeting European Association for the study of diabetes". Madrid, Abstract n ${ }^{\circ} 142$ (1972)

19. Krug, E., Mialhe, P.: Pancreatic and intestinal glucagon in the duck. Horm. Metab. Res. 3, 24-27 (1971)

20. Krug, E., Biehler, E., Mialhe, P.: Molecular weight of gut and pancreatic circulating glucagons in the duck. Horm. Metab. Res. 3, 258-261 (1971)

21. Krug, E.: Personal communication

22. Langslow, D.R., Buttler, E.J., Hales, C.N.: The response of plasma insulin glucose and nonesterified fatty acids to various hormones, nutrients and drugs in the domestic fowl. J. Endocr. 46, 243-260 (1970)

23. Langslow, D.R., Hales, C.N.: Lipolysis in chicken adipose tissue in vitro. J. Endocr. 43, 285-294 (1969)

24. Laurell, S.: Plasma free fatty acids in diabetic acidosis and starvation Seand. J. clin. Lab. Invest. 8, $81-82(1956)$

25. Laurent, F.: Unpublished data

26. Leclercq-Meyer, V., Mialhe, P., Malaisse, W.J.: Une méthode de dosage radioimmunologique du glucagon comportant une séparation par le charbon dextran. Diabetologia 6, 121-129 (1970)

27. Lefebvre, P.: The physiological effect of glucagon on fat mobilization. Diabetologia 2, 130-132 (1966)

28. Luyckx, A.S., Lefebvre, P.J.: Arguments for a regulation of pancreatic glucagon secretion by circulating plasma FFA. Proc. Soc. exp. Biol. 13: $524-528(1970)$

29. Luyckx, A.S., Lefebvre, P.: Changes in insulin and glucagon secretion related to concentrations of metabolic substrates in the isolated rat pancreas. In "Hormones Pancréatiques, Hormones de l'eau et des électrolytes." Colloque INSERM 99-127 (1972)

30. Madison, L. L., Seyffert, W.A., Unger, R.H., Barker, B.: Effect of plasma FFA on plasma glucagon and serum insulin concentrations. Metabolism XVII, 301 $304(1968)$

31. Mialhe, P.: Hypoglycémie et diminution de la tolérance au glucose chez le canard après pancréatectomie totale. C.R. Acad. Sci. (Paris) 241, 1500 $-1503(1955)$
32. Mialhe, P.: Glucagon, Insuline et régulation endocrine de la glycémie chez le canard. Acta endoc. (Kbh.), Suppl. 36, (1958)

33. Mialhe, P.: Does an understanding of experimental diabetes advance the knowledge of spontaneous diabetes? (Studies on glucagon and its possible role in diabetes) Proc. VII congress of IDF Buenos-Aires 843-853 Ed. R.R. Rodriguez. ICS 231, Exerpta med., Amsterdam (1971)

34. Miller, H.I., Bortz, W.M., Durham, B.C.: The rate of appearance of FFA in plasma triglycerides of normal and obese subjects. Motabolism XVII, 515-521 (1968)

35. Müller, W.A., Faloona, G.R., Unger, R.H.: The effect of experimental insulin deficiency on glucagon secretion. J. clin. Invest. 50, 1992-1999 (1971)

36. Samols, E.J., Tyler, J.M., Marx, V., Mialhe, P.: The physiological role of glucagon in different species. Proc. III International Congress Endocrinol. Mexico, Progress in Endocrinol. 206-219 Exerpta med. ICS. 184 Amsterdam Ed. C. Gual (1968)

37. Samsel, J., Mialhe, P., Karmann, H.: Effect of arginine on secretion of pancreatic glucagon, intestinal glucagon and insulin in the duck. Diabetologia $8,65(1972)$

38. Seyffert, W.A., Madison, L.L.: Physiologic effects of metabolic fuels on carbohydrate metabolism. I. Acute effect of elevation of plasma FFA on hepatic glucose output, peripheral glucose utilization, serum insulin and plasma glucagon levels. Diabetes 16, 765-776 (1968)

39. Sitbon, G., Mialhe, P.: Mécanismes de feed-back glucose-glucagon et glucose-insuline chez l'oie. Gen. comp. Endocrinol. 18, 624 (1972)

40. Unger, R.H., Aguilar-Parada, E., Müller, W.A., Eisentraut, A.M.: Studies of Pancreatic alpha cell function in normal and diabetic subjects. J. elin. Invest. 49, 837-848 (1970)

Dr. R. Gross

Institut de Physiologie Générale

Rue René Descartes

Université Louis Pasteur

Strasbourg

France 